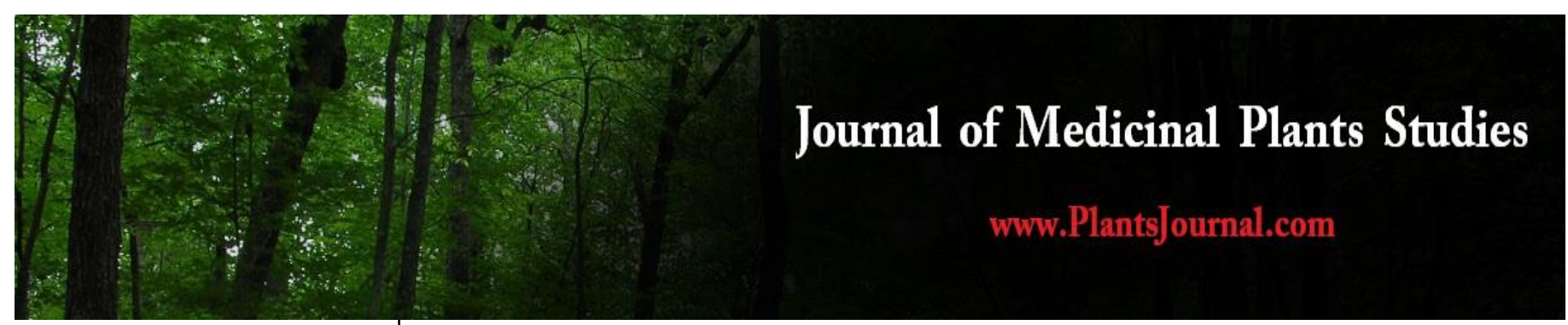

ISSN (E): 2320-3862

ISSN (P): 2394-0530

NAAS Rating: 3.53

www.plantsjournal.com

JMPS 2021; 9(2): 146-150

(C) 2021 JMPS

Received: $\mathrm{xx}-12-2020$

Accepted: xx-01-2021

Dr. Manali Rajendra Bodke

Final Year PG Scholar,

Department of Prasuti Tantra \&

Stree Roga, S.V.M Ayurvedic

Medical College, Ilkal, Bagalkot,

Karnataka, India

Corresponding Author:

Dr. Manali Rajendra Bodke

Final Year PG Scholar,

Department of Prasuti Tantra \&

Stree Roga, S.V.M Ayurvedic

Medical College, Ilkal, Bagalkot,

Karnataka, India

\section{Uttar basti: Importance in management of infertility}

\section{Dr. Manali Rajendra Bodke}

DOI: https://doi.org/10.22271/plants.2021.v9.i2b.1266

\section{Abstract}

Infertility is a common problem affecting one couple in six. Infertility is a failure of conceiving within 1 year of regular unprotected coitus. According to the Indian Society of Assisted Reproduction, Infertility currently affects about 10- $14 \%$ of the Indian population, with higher rates in urban areas According to sushruta, woman, in whom Artava has been destroyed, is termed as Vandhya which is termed as Infertility in Modern Science. According to Acharya Sushruta the four main factors required for the proper conception are Ritu (Ovulatory period), Kshetra (endometrium), Ambu (Hormones) and Beej (Ova and Sperm). Abnormality in any of these factors leads to vandhyatva, only a suddha yoni and garbhasya can conceive properly. Diseased yoni may lead to habitual abortion or infertility. As per Ayurveda Uttar basti (insertion of medicated oil or decoction through vagina and uterus) after shodhan, is indicated as the line of treatment of kshetra. Indications of Uttar basti are mentioned in our classics. Vata dosha is the prime cause of Vandhyatva (Infertility) and Uttar basti is Vata-shamak \& has Ropan and Shodhan property, so uttar basti is be the best line of treatment in Infertility (Vandhyatva).

Keywords: infertility, Uttar basti, Vandhyatva

\section{Introduction}

Infertility is defined as a healthy couple, unable to achieve pregnancy with 1 year of regular unprotected coitus ${ }^{[1]}$. Ayurveda has been successfully treating infertility since ancient times, without the help of modern $\&$ advance medicine, as it provides ability to infertile women or couples through treatment of Ayurveda, to become fertile and also to improve the overall health of the women so that she can conceive naturally without the aid of western medicine ${ }^{[2]}$. Women are blessed with the ultimate gift of being a mother but if she could not be a mother, it is most disappointing. The word Vandhya is derived from the root "vandh" with "yak" suffix, which means barren, unproductive, fruitless so the woman in whom there is hindrance of any kind to the normal process of conception is called vandhya. According to sushruta, woman, in whom artava has been destroyed, is termed as vandhya ${ }^{[3]}$. As per ayurveda uttar basti after shodhan, is indicated as the line of treatment of vandhyatva (infertility). Indications of uttar basti are mentioned in our classics. Vata dosha is the prime cause of vandhyatva (infertility) and uttar basti is vata-shamak \& has ropan and shodhan property, so uttar basti is be the best line of treatment in vandhyatva ${ }^{[4]}$.

\section{Infertility (Vandhyatwa) \\ Definition}

Infertility is defined as the incapacity to Conceive after a Year or more of Regular sexual intercourse with no contraceptive measures taken ${ }^{[1]}$. In contrast, the fertile population is defined as those who do become pregnant after some reasonable time of regular sexual intercourse.

Four Important factors required for Conception: ${ }^{[5,7]}$

1) Rutu (fertile period/Ovulation Phase)

2) Kshetra (reproductive organs/Uterus/Endometrium)

3) Ambu (Hormones)

4) Beeja (Ovum) 
A healthy psychological Atma, satva, satmya, rasa). Any abnormality in any of these factors causes infertility

\section{Types of infertility as described in classical texts}

A) As per Charaka samhita 3 Types

1) Vandhya: refers to absolute inability to conceive due to serious innate problems like beejopaghata (absolute congenital chromosomal or Mullerian agenesis abnormalities) ${ }^{[8]}$.

2) Apraja: refer to infertility in which woman conceives after treatment (primary infertility) or a woman with unsuccessful pregnancies even after obtaining conception [9].

3) Sapraja: refer to a condition in which a woman in her active reproductive age does not conceive with previous history of bearing successful pregnancies ${ }^{[10]}$.

B) As per Harita samhita 6 Types ${ }^{[11]}$

1) Kakavandhya: unable to conceive after one child.

2) Anapatya: Primary sterility where the lady never conceives.

3) Garbhasravi: characterized by unsuccessful pregnancies due to repeated abortions.

4) Mritavatsa: characterized by unsuccessful pregnancies due to repeated intrauterine death, still births and perinatal deaths.

5) Balakshaya: Infertility due to loss of Bala (strength) or dhatukshaya.

6) Balya: If the coitus is done with a girl before her menarche it results in constriction of uterus and Bhaga and this woman does not conceive or conceives quite late with great difficulty.

\section{Etiology of Vandhyatwa}

Vandhyatwa is a multifactorial disease. To understand the pathology of conception, it is very necessary to go through the physiology of conception i.e the factor essential for
Vata, Shadbhava (Six factors - mother, father. conception.

\section{According to Acharya charaka ${ }^{[12]}$}

Matruja and Pitruja: Shonita (Stribeeja) and Shukra (Pumbeeja) should be normal.

Aatmaja and Satvaja: Aatma encircled with satva descents in the fertilized egg and forms garbha. Formation of garbha is not possible without aatma and satva.

Satmyaja and Rasaja: The normalcy of shonita and shukra greatly depend upon the use of Satmya Aahara and Vihara. The nourishment of mother and embryo depend upon the Rasa.

So, any abnormality of Garbhakara-bhavas i.e shad-bhawas will cause failure to conceive.

\section{Uttar basti}

\section{Definition}

The Basti which is given through uttar marga or utkrishta avayava or therapeutic procedure having shreshtha properties, is termed as uttar basti. Uttar Marga Means, Mutra \& Shukra Marga in Males and Mutra \& Yoni Marga in Females ${ }^{[13]}$.

\section{Properties of Uttar Basti}

Uttar Basti is useful to alleviate Artava Dushthi, Shukra Dushthi, Atya-artava, Kashtha-Artava, Yoni Vyapads and other factors related to Vandhyatwa ${ }^{[14]}$.

\section{Utter basti yantra}

Instrument by which insertion of drug by urinary or vaginal passage is to be done is called as utter basti yantra. It can be used as shodhan bsti. It is given through upper passage (Uttar Marga) which is why, it is called as Uttar basti.

\section{Uttar Basti Types}

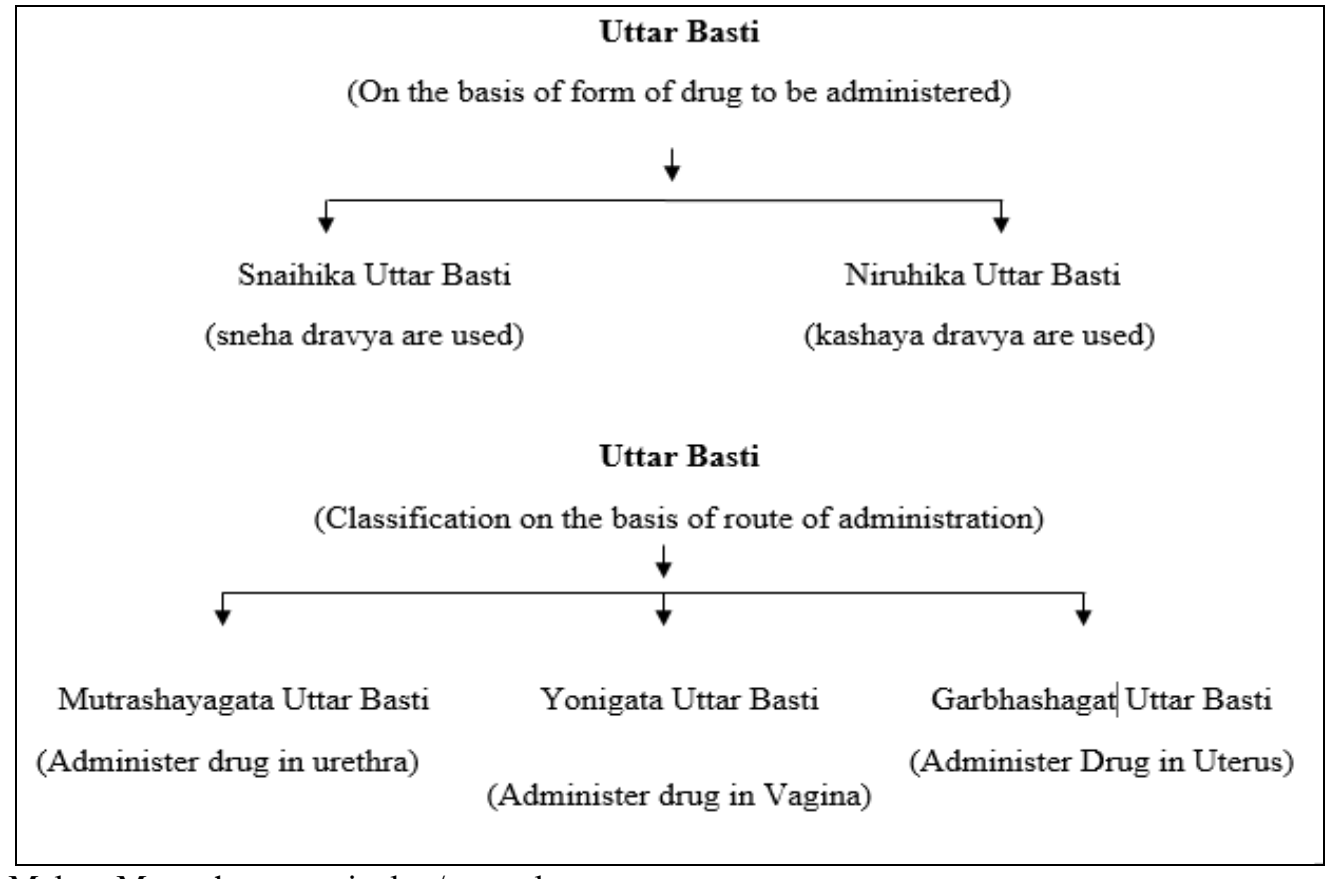

Male = Mutrashaya - vesicular / uretral route

Female $=$ Yoni marga $/$ garbhashaya

Uttar basti contains two parts

1. Basti Putak (drug holding bag)
2. Basti Netra (nozzle for inserting drug)

\section{A) Basti putak}


Basti putak can be made up of urinary bladder or skin of animals like goat, Pig and sheep or thick cloth etc. It should be Clean \& without Foul Smell processed with Kashaya Dravyas ${ }^{[15]}$.

\section{B) Basti Netra}

Basti Netra (nozzle) should be made up of metal like gold, silver, brass etc. In shape it should be tapering like cow's tail and smooth. Its tip should be of the size of the flower stalk of jati, karveera, and the sarshapa seed passing worth lumen. The nozzle should have two or three karnikas (rings) to tie up the bag and having the length of ten or fourteen angulas. For inseration through urthra the nozzle should have mudga seed passable lumen and ten angulas in length. It is also called as Pushpa Netra ${ }^{[16,17]}$.

\section{Length of basti Netra to be inserted}

For women who has delivered a baby or who is in active reproductive age, four angulas (around $4 \mathrm{~cm}$ ) nozzle should be inserted in urinary passage. Uttar basti should not be given to unmarried girls in vaginal passage ${ }^{[18]}$.

\section{Administration of Uttar Basti}

\section{Time to Administer Uttar Basti ${ }^{[19]}$}

1. After shodhana of women, uttar basti should be given during Ritukala (follicular phase or just after menses) as orifices of uterus remain open in this period.

2. Charaka told Rutukala is the most suitable time for the administration of uttar basti.

3. Uttara basti should be given after 2-3 asthapan basti during rtukala, as during this period the yoni or garbhashaya is avarana rahita and so sneha enters \& absorb easily.

\section{Basti Matra ${ }^{[20,23]}$}

1. Acc.to Charaka: 20gms-3time (3days)

2. According to Susruta: Male: 96 gms (1 prastrita), Female; 192 gms (2 prastrita)

3. Sneha should be taken double quantity for uterine douch or cleaning.

4. Decoction: Male: 96 gms (1 prastrita), Female: 192 gms (2 prastrita), kanya:1 prasara

5. Sneha: Male: 48 gms, Female: 96 gms

6. Acc. To vangsen, Max. 4 tola

7. below 25 years -2 karsh

\section{Uttara Basti Karma Vidhi ${ }^{[18,19]}$}

\section{Purava Karma}

1. As per the derivation of the word uttara basti, Uttara basti should be given after the administration of niruha basti, according to vagbhata, about 2 or 3 Niruh basti should be given before the administration of uttara basti.

2. Abhyanga and swedan karma should be done preferably over the back, groin and abdomen then yavagu added with ghee should be given for drinking.

\section{Pradhana Karma in Female}

1. The patient is made to lie down on her back. Then she is made to fold her legs at knee (lithotomy position).

2. Then the uttara basti yantra containing the prescribed dravya (either kvatha or sneha) is taken and the basti

3. Netra lubricated with sneha is carefully introduced into the apathya marga.

4. Basti putpak is compressed uniformelly, so that the dravya can enter the yoni.

5. It is practically observed that kvatha returns immediately wheres sneha is retained after some time.

6. Such uttara basti can be repeted 2-3 times, in a day and also has to be given consecutively for 3 days.

7. Then the patient is advised rest for 3 days before giving another course of uttara basti.

\section{Pradhana Karma in Male}

1. The patient should be brought to basti room and advised to sit on the stool having the height equal to the knee of the patient. The penis is made to erect.

2. Then the basti yantra containing the kvatha or sneha is taken and the basti netra as well as the urethral meatus is lubricated with sneha.

3. Netra is carefully introduced into the mutramarga (urethara) and basti putpak is compressed uniformly.

4. Then remove the netra by leavieng some oil in putpaka.

\section{Paschat Karma}

1. Rest for some time is advisable.

2. As far as diet intake is concerned, Acharya suggest that after the pratyagamana of uttar basti, at evening the patient should be given milk or yusha.

\section{Procedure of Uttara basti}

Before administration of uttar basti previous infection should be cleared. After this, 2 to 3 Asthapana basti should be given to the patient. The woman should be placed in supine position with flexed thighs and elevated knee. After that Basti Netra should be inserted in vaginal passage slowly with steady hand, following the direction of passage then drug should return after some time if not return then again niruha basti or varti of purifying drugs should be used uttarbasti procedure should be carried out by an expert, under all aseptic precautions and sterilized instruments is to be used so there are no any chance of introducing any kind of infection.

\section{Instruments Required for Uttarbasti}

1. Sponge holding forceps

2. Sim's speculum

3. Anterior vaginal wall retractor

4. Vulsellum /Allis forceps

5. Uterine sound

6. Cervical dilator (if necessary)

7. IUI cannula

8. 5 cc syringe

9. 9 Gauze pieces

10. Gloves

11. Towel clips

12. Good light source

\section{Pre- Preparation for Uttar Basti}

1. Counselling is done.

2. Written consent is taken.

3. Part preparation is done prior to procedure.

4. Instruments are checked and trolley is prepared.

5. Luke warm medicine is kept ready in IUI canula

6. Yoni prakshalana with some antiseptic kwatha is done properly this is followed by snehana of abdomen, back, thighs and legs followed by svedana especially nadisweda on back and lower abdomen.

\section{Procedure for Uttar Basti}

1. Patient is asked to empty the bladder \& to lie in lithotomy 
position on examination table.

2. Private parts are cleaned antiseptically.

3. Sim's speculum is inserted, anterior vaginal wall retractor is introduced to expose the vagina \& cervix.

4. Anterior lip of the cervix is held with the vulsellum or Allis forceps (to reduce the injury to cervix)

5. Uterine sound is introduced to see the length of uterocervical canal and position of the uterus. IUI cannula is introduced the drug is injected slowly and steadily.

6. Instruments are removed out.

\section{Post- Procedure to Uttar Basti}

1. Patient was advised to extend and twist her legs, head low position given for $15 \mathrm{~min}$.

2. Pulse and blood pressure recorded for two hours.

3. It is important to watch and observe that the basti dravya was expelled out properly or not and then a sterilized gauze piece kept into vagina and patient was advised to remove it after 2 hours.

4. Abdominal hot fomentation should be given which is followed by light diet.

5. Avoid the intercourse for 3-5 days post the procedure.

\section{Mode of action of uttar basti Local effect of uttar basti ${ }^{\text {[24] }}$}

Effect of uttar basti highly depend on factors like methods, instrument and drug used etc. If the medicine is put in cervical canal it may act more on the cervical factors. For the factors like cervical stenosis, a katu ushana taila based medication can be more useful, while for increasing secretion of mucus from cervical glands, a nutritive and madhur-shita ghrita based medicine will be more effective. In the same way, the drug selection for ovulatory and tubal factor will be totally different from each other. On ovary the effect of drug will be after absorption and then by promoting the hypothalamic pitutary-ovarian axis. While in tubal block uttar basti acts locally. In ovulation, a drug with snehan property can be good while for the tubal block a drug with lekhana karma will be better. Uttar basti may also stimulate certain receptors in the endometrium leading to correction of all the physiological processes of reproductive system. Intravaginal uttar basti may also facilliate the absorption of drug as posterior fornix has a very rich blood supply and it may also act as reservoir of drug.

\section{Systemic effect of Uttar Basti after absorption ${ }^{[25]}$}

It seems that Ayurveda had a clear distinguishing approach between oral and parenteral route of drug administration from the very beginning. Uttar Basti may act by stimulating some neuro-endocrine pathways after getting absorbed. Systemic effect of Uttar Basti also be understood with the help of systemic biology concept. Systemic biology is the latest concept emerging and getting accepted in modern science. This concept believes in the holistic approach and believes that all the bodily systems and organs are interconnected at molecular level. And any change in any organ molecular level will certainly change the other. This concept is actually the first step of modern science toward the concept of Mahabhut and tridosha. The effect of Uttar Basti drugs, have on the physiology of reproductive system, it will definitely involve the physiological functions and corrections of other organs.

\section{Discussion}

Infertility in Females has turned out to be a major Concern which is a Result of the Current Life style which has affected to lack of conception and reproducibility. Today's Era and the working culture has resulted in stressful world, excess radiation, lack of biological food, genetic disorder, increased electronic usage, have eventually resulted the female infertility. Infertility/childlessness cause great personal suffering \& distress. According to Ayurveda the four factors are responsible for healthy conception, these are ritu, kshetra, ambu, and beeja. Abnormality in any of these factors leads to vandhyatva, only a suddha yoni and garbhasya can conceive properly. Diseased yoni may lead to habitual abortion or infertility. Uttar basti (insertion of medicated oil or decoction through vagina and uterus) after shodhan is indicated as the line of treatment of kshetra. Indication of uttar basti is mentioned in our classics to Treat Infertility. Vata dosha is the prime cause of yoni-vyapad and uttar basti has vatashamak as well as ropan and sodhan property, so uttar basti is the best line of treatment of vandhyatva.

\section{Conclusion}

Western Medicine has many options medicinal or Surgical treatments for infertility but it may cause side effects and are costly for Patients. Whereas Ayurveda has mentioned many treatments like Basti and various drug combination with minimum side effects and are cost effective so can be used as first line of treatment. Basti is the main treatment of Vata dushti. Uttar basti is the main line of treatment of Vandhyatva (Infertility) as it strengthens the garbhasya by applying proper drug through Uttar basti. Uttar basti have lot of therapeutic potential. Proper selection of drug and timely administration is very essential for getting the desired results.

\section{References}

1. Sharma PV. Charaka-Samhita. Agniveshaes Treatise, Refined and Annotated by Charaka and Redacted by Dridhabala, Vol II., (Chaukhambha Orientalia, Varanasi, 1981-1994), Chapter XXX, Page 502, Verses 1-40.

2. KR Srikantha Murthy, Astanga Hrdayam Volume 3 (Krishnadas Ayurveda Series 2010, Chapter 4.

3. Sushruta Samhita By Ambika Dutta Shastri Part 1st \& 2nd, Chaukhambha Sanskrit Sansthan, Varanasi, reprint edition 2012, Uttarstana 38

4. Ayurveda deepika commentary charaka Samhita, chaukambha krishnadas academy, Varanasi chikitsa sthan 2011;30(46).

5. Sushruta Samhita By Ambika Dutta Shastri Part 1st \& 2nd, Chaukhambha Sanskrit Sansthan, Varanasi, reprint edition 2012.

6. Sushruta Samhita By Ambika Dutta Shastri Part 1st \& 2nd, Chaukhambha Sanskrit Sansthan, Varanasi, reprint edition, Sha 2012;3(5):26.

7. Bhava Prakasha (part 1\&2) Bhavamishra with Vidhyotini Hindi commentary by Shri Brahma Shankar Mishra, 9th edition, purvakhanda garbhaprakarana 1999;3(2):20.

8. Agnivesha, Charaka, Dridhbala, Charaka Samhita, elaborated Vidyotini Hindi Commentary by Pt. Kashinatha Shastri and Dr. Gorakha Natha Chaturvedi, Part-1,2 Chaukhamba Bharti Academy, Varanasi, Sha 2014;4(30):877.

9. Agnivesha, Charaka, Dridhbala, CharakaSamhita, elaborated Vidyotini Hindi Commentary by Pt. Kashinatha Shastri and Dr. Gorakha Natha Chaturvedi, Part-1,2 Chaukhamba Bharti Academy, Varanasi Ch. Ch 2014;30(16):842.

10. Agnivesha, Charaka, Dridhbala, Charaka Samhita, elaborated Vidyotini Hindi Commentary by Pt. 
Kashinatha Shastri and Dr. Gorakha Natha Chaturvedi, Part-1,2 Chaukhamba Bharti Academy, Varanasi 2014, Ch. Sha 2014;2(7):838.

11. Harita Samhita, Trutiya Sthana Hariharprasad Tripati, Chaukambha, Krishnadas Academy, Varanasi, Edition 2th 2009;48(2-6):448.

12. Agnivesha, Charaka, Dridhbala, Charaka Samhita, elaborated Vidyotini Hindi Commentary by Pt. Kashinatha Shastri and Dr. Gorakha Natha Chaturvedi, Part-1,2 Chaukhamba Bharti Academy, Varanasi, Ch. Sha 2014.

13. Acharya Mukundilal Dwivedi. Ayurvediya Panchakarma Chikitsa, Delhi: Chaukhamba Sanskrit Pratishthan, Reprint 2017, P. 9

14. Kaviraj Ambikadatta Shastri. Sushruta Samhita,Varanasi : Chaukhamba Sanskrit Sansthan; Reprint, Chikitsa Sthan 2018;38(125):126-207

15. Kaviraj Ambikadatta Shastri. Sushruta Samhita,Varanasi : Chaukhamba Sanskrit Sansthan; Reprint, Chikitsa Sthan 2018;37(107):205

16. Dr. Brahmanand Tripati, Ashtanghrudaya, Delhi: Chaukhamba Sanskrit Pratishatan; Sutrasthan, Chapter no 19(72):240

17. Mukundalal Dwivedi. Ayurvediya Panchakarma Chikitsa, Delhi: Chaukhamba Sanskrit Pratishtan; Reprint, chapter no 2017;10:915

18. Dr. Brahmanand Tripati.Ashtanghrudaya, Delhi: Chaukhamba Sanskrit Pratishatan; Sutrastan, Chapter no 19(70):240-241

19. Kaviraj Ambikadatta Shastri. Sushruta Samhita,Varanasi : Chaukhamba Sanskrit Sansthan; Reprint, Chikitsa Sthan, chapter no 2018;37(108):205

20. Shri. Kashinath Shastri \& Shri. Gorakhnath Chaturvedi. Charak Samhita, Varanasi; Chaukhamba Bharati Academy; Reprint, Sidhisthan, chapter 1998;9(62):1065.

21. Dr.Brahmanand Tripati. Ashtanghrudaya, Delhi: Chaukhamba Sanskrit Pratishatan; Sutrasthan, Chapter no 19(80)242

22. Dr. Brahmanand Tripati. Sharangdhar Samhita, Varanasi; Chaukhamba Sulabha bharati Prakashan; Reprint, Uttarakhanda, Chapter no 2019;7(2):242

23. Kaviraj Ambikadatta Shastri. Sushruta Samhita,Varanasi : Chaukhamba Sanskrit Sansthan; Reprint, Chapter no 2018;37(106):205

24. Vd. Sarvesh Kumar Singh \& Vd. Kshipra Rajoria, A Textbook of Panchakarma, Varanasi, Chaukhamba Prakashan, chapter no 8:518-519

25. Anup Jain. A textbook of panchakarma, New Delhi: Jaypee brother medical publishers: Reprint, chapter no 2019;6:403-404 